\title{
THE WOLF AS A SHEPHERD: ICONOCLASTIC READINGS ON THE FEAST OF ICONS AND ITS LEGACY
}

\section{EL LOBO COMO PASTOR: LECTURAS ICONOCLASTAS SOBRE LA FIESTA DE LOS ICONOS Y SU LEGADO}

\author{
Haris Ch. Papoulias ${ }^{1}$ \\ Hercritia-UNED Madrid (España)
}

\begin{abstract}
A very special kind of feast belongs to the Christian Orthodox tradition: there is a specific liturgical celebration of the Images in the so-called Sunday of Orthodoxy. While in many cultures images are employed in order to celebrate an historic event, this is the only feast in which, on the contrary, images are celebrated for themselves. Nonetheless, the role of images in Orthodoxy is not univocally and positively accepted. In fact, the title's expression «the wolf as a shepherd» belongs to a Desert Father and refers to the role of images in our mental life. This is not reported by a heretical iconoclastic document, but by the well-known Philokalia, a kind of handbook of Orthodox Aesthetics. This paper aims to present these two aspects in their paradoxical partnership. First, I will present some historical, symbolic and liturgical aspects of this feast. Thus, we should be able to understand better why many contemporary authors claimed that the origins of our visual culture can be traced in this Feast. However, if we comprehend the philosophical value of Byzantine icons, we realise that they have little to do with our contemporary images, no matter whether we mean artistic, religious or media images. We often talk about the "power of images», but just to blame them -as if they were autonomous entities- or to praise them, in a generalized aestheticization of contemporary life. Iconophobia and iconodoulia, I claim, are emerging as ontologically impoverished versions of the former Byzantine theoretical models. What falls into oblivion is the paradoxical status of the image as «appearance of the essence of Being» that demands as a condition of its own existence its self-sublation. These dialectics, conceptually inspired by the Hegelian logic, are fully present in Byzantine Aesthetics, where the feast is considered as a precarious image, held in memory of a future image-loss event known as eschaton.
\end{abstract}

Key words: Feast of Icons; Iconoclasm; Images; Hegel; Byzantine Aesthetics.

[1] (haris.papoulias@uniupo.it) Haris Papoulias es Doctor en Filosofía y Doctor Europaeus. Es miembro del Grupo de Investigación sobre el Idealismo Alemán y sus Consecuencias Actuales de la Universidad de Málaga. Es autor del libro Iconoclastia endogena. Una teoria dell'immagine hegeliana. Saggio introduttivo di Félix Duque, Milán: Mimesis 2019, y de diversos artículos en revistas nacionales e internacionales. Sus líneas de investigación son la cultura visual griega y la filosofía alemana. 
Resumen: A la tradición cristiana ortodoxa le pertenece un tipo muy especial de fiesta: en el, así llamado, domingo de la Ortodoxia hay una celebración litúrgica de las imágenes. Mientras que en muchas culturas las imágenes son empleadas para celebrar un evento histórico, ésta es la única festividad en la cual, por el contrario, las imágenes son celebradas por sí mismas. No obstante, el papel de las imágenes en la Ortodoxia no se acepta de modo unívoco y positivo. De hecho, la expresión del título «el lobo como pastor» pertenece a un padre del desierto y se refiere a la función de las imágenes en nuestra vida mental. Esta expresión no aparece en un documento iconoclasta herético, sino en la célebre Philokalia, una suerte de manual de estética ortodoxa. El objetivo de este artículo estriba en presentar esos dos aspectos en su parentesco paradójico. Primero, presentaré algunos aspectos históricos, simbólicos y litúrgicos de esta fiesta. Así estaremos en condiciones de comprender mejor por qué muchos autores contermporáneos afirman que los orígenes de nuestra cultural visual pueden ser ubicados en esta fiesta. Sin embargo, si comprehendemos el valor filosófico de los iconosw bizantinos, nos daremos cuenta de que tienen poco que ver con nuestas imágenes contemporáneas, sin importar que nos refiramos a imágenes artísticas, religiosas o de los medios de comunicación. A menudo hablamos acerca del «poder de las imágenes», pero lo hacemos para culpabilizarlas - como si se tratase de entidades autónomas-o para alabarlas, en una estetificación generalizada de la vida contemporánea. Afirmo que tanto la iconofobia como la iconodulia emergen como versiones empobrecidas ontológicamente de los anteriores modelos teoréticos bizantinos. Lo que se olvida es el estatus paradójico de la imagen como «apariencia de la esencia del ser» que exige como condición de su propia existencia su auto-disolución. Esta dialéctica, inspirada conceptualmente por la lógica hegeliana, permea por completo la estética bizantina, en la que la fiesta es considerada como una imagen precaria, sostenida en la memoria de un acontecimiento futuro de pérdida de la imagen, conocido como eschaton. .

Palabras clave: Fiesta de los Iconos; Iconoclasia; Imágenes, Hegel; Estética Bizantina 


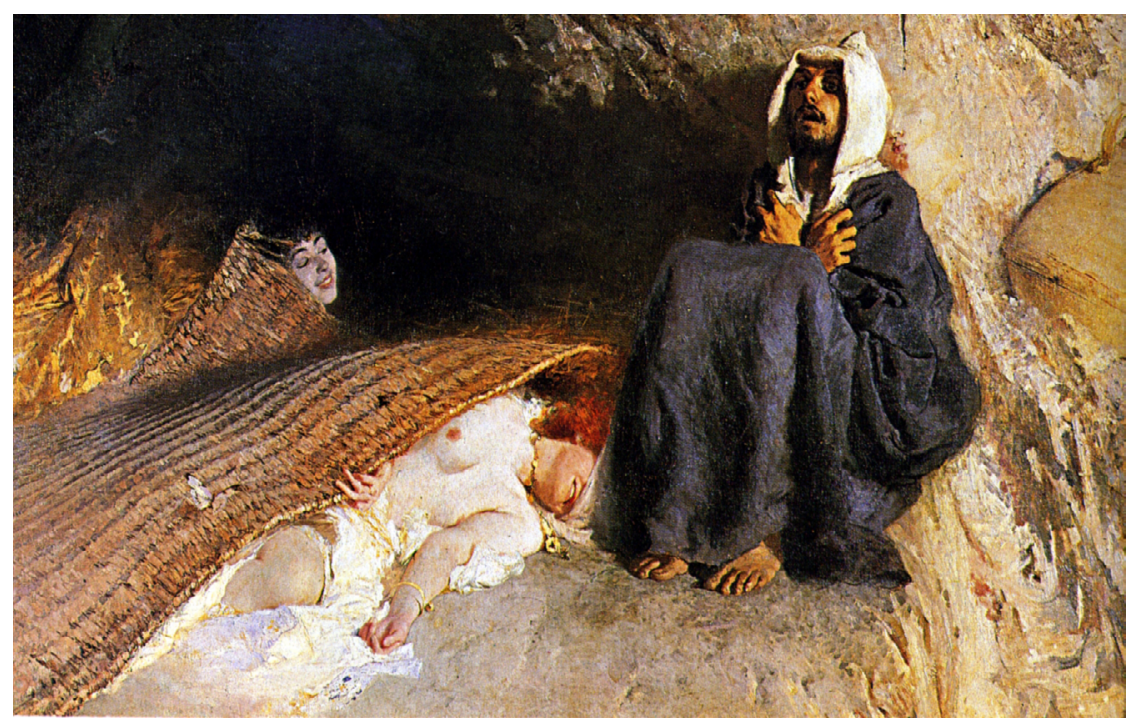

D. Morelli, Le tentazioni di Sant'Antonio, 1878, oil on canvas, $137 \times 225 \mathrm{~cm}$, Galleria Nazionale d'Arte Moderna, Roma.

\section{Introduction}

The feast of icons, celebrated every year on the 1st Sunday of the Great Lent, is one of the most important feasts of the Orthodox Church. What is celebrated is the historical event of the so-called «Restoration of Icons», i.e. the end of the long Byzantine civil war that took place in the 8th and 9th cent. AD. This feast is so important that it is commonly known as «Sunday of Orthodoxy", i.e. the feast of the Eastern Church par excellence. Just by thinking these terms in the form of an equation, we can easily understand that for the Eastern Church, to celebrate the Icons means to celebrate latterly the óp $\theta$ ń $\delta$ '́za (ortho-doxy). ${ }^{2}$

Contrary to what many people believe, the feast of icons is not just an act of legitimacy of the images; this was truly an historical aspect of

[2] It is not easy to give unequivocally the translation of this word. Many people translate it as «right thought» or «true faith», but a very concise way to understand it, it is given by J. Ratzinger and I think it would be accepted by any Orthodox theologian: «It may be useful here to recall that in the word «orthodoxy», the second half, «-doxa», does not mean «idea» but, rather, «glory»: it is not a matter of the right «idea» about God; rather, it is a matter of the right way of glorifying him, of responding to him. For that is the fundamental question of the man who begins to understand himself correctly: How must I encounter God? Thus learning the right way of worshipping - orthodoxy_is the gift par excellence that is given to us by the faith"; see his introduction to his Collected Works: Theology of the Liturgy, The Sacramental Foundation of Christian Existence, Ignatius Press, San Francisco 2014. 
the issue of unimaginable consequences. Many contemporary authors believe that it was one of most crucial turning points for the development of the entire western society towards an image-society. Régis Debray, for instance, in his influential book Vie et mort de l'image, explains in a few lines the central argument of the Byzantine debate and its actuality:

the West possesses the figurative genius because twenty centuries ago appeared in Palestine a heretical Jewish sect with [...] the dogma of the Incarnation. Thus, flesh could become, oh! what a scandal!, the 'tabernacle of the Holy Spirit'. A divine body which is material, therefore, could have a material image. It is out of there that Hollywood comes: out of the icon and the baroque. ${ }^{3}$

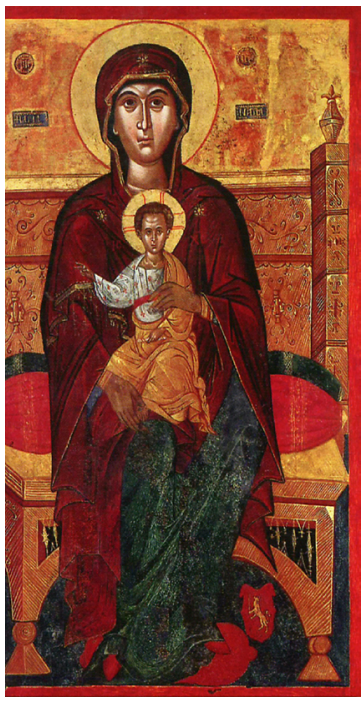

Icon

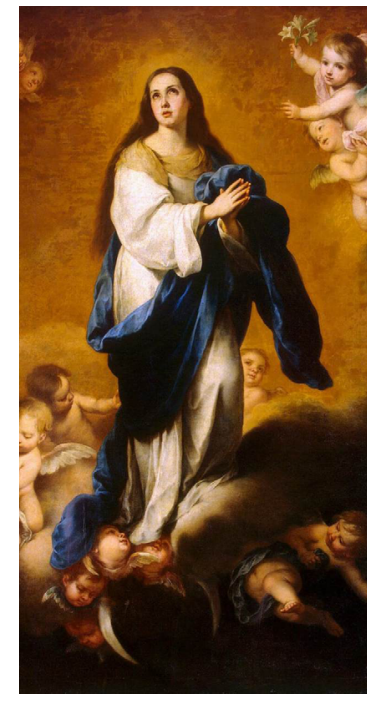

Baroque

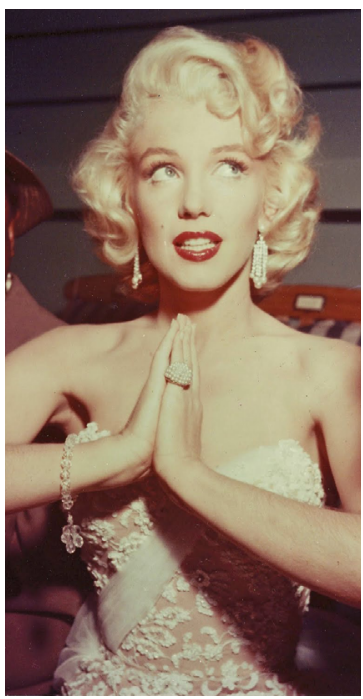

Hollywood

Just in three words we could recognize our whole visual culture. Even so, the paradoxes are many. What does Holy Mary have to do with Marilyn? Is Marilyn «holy» too? Or is Mary a potential star of Hollywood? It is surprising but many issues of modern visual studies have been already discussed in the Byzantine era. A civil war that lasted more than a hundred years, perhaps could highlight at least a positive aspect that could be really attractive to our interests: they were taking images very seriously. Nevertheless, as I was saying, it was not just a question of justification on every use of images.

[3] R. Debray, Vie et mort de l'image: une histoire du regard en Occident, Gallimard, Paris 1992, p. 75. 
Much better, it could be said that the Byzantine era marks one of the strictest moments of a real regulation of the image-production, defining also the right behavior towards them. Only by taking this premise seriously, we may also understand how it is possible to find many Church Fathers within Orthodoxy, expressing apparently thesis against images. The «image» of the Wolf as a Shepherd, for instance, is taken by an author who did not like images at all: a so-called «desert father», namely Evagrios the Solitary. His «iconophobia» has not a direct link to the latter iconoclastic controversy; moreover, his teachings are collected in a well-known compilation called Philokalia, or in modern terms: a kind of «Companion to Orthodox Aesthetics» ${ }^{4}$ : He said:

Do not long to have a sensory image of angels or powers or Christ, for this would be madness: it would be to take a wolf as your shepherd and to worship your enemies, the demons. Self-esteem is the start of illusions in the intellect. Under its impulse, the intellect attempts to enclose the Deity in shapes and forms. (...) blessed is the intellect that is completely free from forms during prayer. ${ }^{5}$

I suggested before that contrary to what it seems, words like these are not in contrast with the liturgical admission of images. We do not deal with an iconoclast in

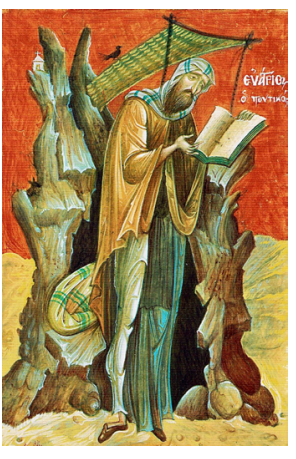
the sense of the historical ones. Many Orthodox today, in their effort to maintain the purity of their doctrine, they try to prove the inconsistency of texts or authors like the one we saw. When something appears contradictory, it is always easier to deny it than comprehend it, particularly where things become complicated. ${ }^{6}$ However, I firmly believe that if the iconophilic doctrine

[4] $\Phi$ ı $\lambda_{0-\kappa \alpha \lambda i}$ i , literally: «love of the beautiful». It is known that what we call Aesthetics, even if it sounds Greek, in reality is a neologism; if we should really search for a Greek term that would be Philokalia; nevertheless, the literal meaning could lead us once again to misunderstandings. It is very significant the «definition» of Kallistos-Ware, not only the editor of the English edition of Philokalia, but also one of the most important contemporary Orthodox theologians: «The Philokalia is an itinerary through the labyrinth of time, a silent way of love and gnosis through the deserts and emptinesses of life, especially of modern life, a vivifying and fadeless presence»; see: The Philokalia, vol. I, Faber \& Faber, London 1984, p. 13.

[5] Philokalia, cit., vol. I., p. 68.

[6] A characteristic operation is the one promoted regarding the re-consideration of Epiphanius of Salamis, an author that traditionally has been considered as an ante litteram iconoclast. Being also an important figure among the Fathers of the Church, it seems that a great effort has been attempted in order to rehabilitate him, declaring spurious his iconoclastic thesis. See: S. Bigham, Epiphanius of Salamis, Doctor of Iconoclasm? Orthodox Research Institute, Rollinsford 2008 
resulted so powerful during centuries, it is because of its ability to include, absorb and finally overcome the opposite demands - not by denying them. ${ }^{7}$

\section{The feast as Memory of the Past: The Restoration of Icons.}

The Feast of Icons has its own icon of the feast, an icon that represents what historical$l y$ happened. It, precisely, represents the first celebration that took place in Constantinople, on Sunday, March $11^{\text {th }}$, 843. In the upper middle, you can see the Icon of Mary, called «Hodegetria», «Guide» or "Directress», held by two angels. On the left we see the Empress Theodora and her son Michael III. On the right, usually are depicted Patriarchs Methodios an d Tarasios, while the crowd that surrounds the icon is composed of many saints who struggled against iconoclasts.

Iconoclasm appeared around 720, when Emperor Leo III took measures against the use, or the

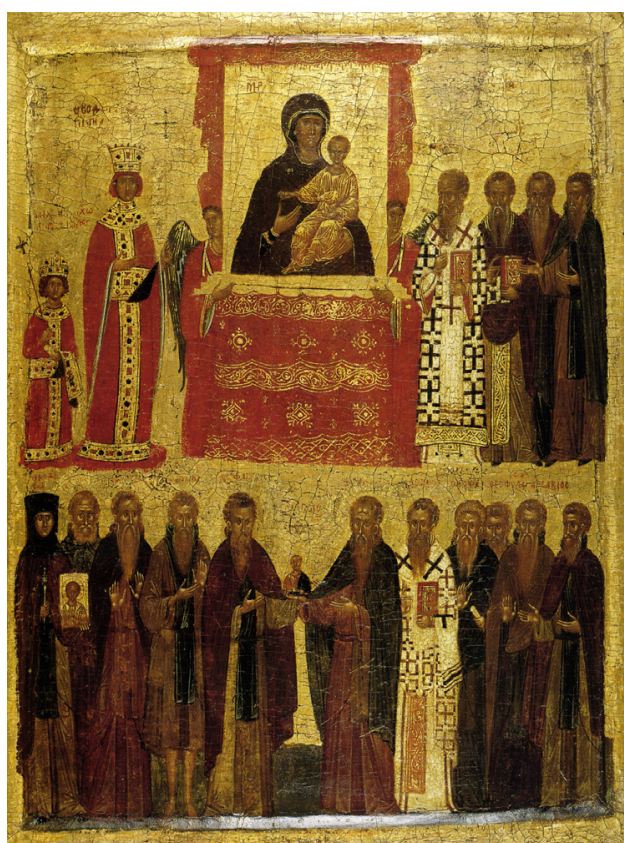

The "Triumph of Orthodoxy", late 14th century, National Icon Collection, British Museum. abuse, of icons. It is said that the icons where treated as if they were magic objects, or even as real persons. Consequently, a reaction to this situation became necessary. The Emperor Constantine V, son of Leo III, is well known for his attempt to give a theoretical basis to iconoclasm convoking a Council that took place in the city of Hieria in 754. After his death, his son Leo IV succeeded him but his reign lasted only five years. His wife, Irene from Athens, instead, gave her protection to the party of the iconophiles. It is said that once the Emperor discovered some icons hidden in her room, he never slept with her again. After his death, she became the first female regnant of an Empire in the western world. At the beginning, she secretly supported the iconophile

[7] It was particularly the Russian theologian Leonid Ouspensky that highlighted well this aspect; see: L. Ouspensky, La théologie de l'icône dans l'Eglise orthodoxe, Éditions du Cerf, Paris 1980. 
party and then, when she ascended the throne, she tried straightforwardly to restore the icons. That finally happened in 787, when the 7th Ecumenical Council took place in the city of Nicaea, a city significantly full of symbolical value because of the first Council of Nicaea (325) where the Creed of Christendom was established. In a certain way, this second Nicaean Council was conceived as a continuation, or as a development of the very same original Creed, extended now explicitly to the matter of images.

In the sixth section of the Council, all the thesis of the previous iconoclastic synod had been treated and abolished, one-by-one. Even if no iconoclastic sources survived, through this critique today we can partially reconstruct them. Another event that is worthy to be mentioned here is what happened at the end of the fifth Section of the Council. Usually, as a sign of the supreme authority of the Holy Word, the Gospel was placed in the middle of the room where every act was held. Now, for the first time, an icon too was placed alongside to show that image and word are of equal seniority. Even so, this seniority did not last a long time. In a few years, the second iconoclastic wave came forth. This period of iconoclasm begins with Leo V, the Armenian. His importance is not limited just to the renewal of the iconoclastic Synod (in 815) but he made a great effort in every field of knowledge and culture, by promoting and supporting many intellectuals, philosophers and scientists, creating the so-called «first byzantine humanism». All these aspects are often eclipsed by the historical critic of the "winners", but we should keep them in mind in order to understand better the complexity of this period.

For instance, we may notice that all iconoclast Emperors promoted their portraits on coins. After Justinian II, ordinarily it should have been Christ depicted on coins, but instead iconoclasts put their own

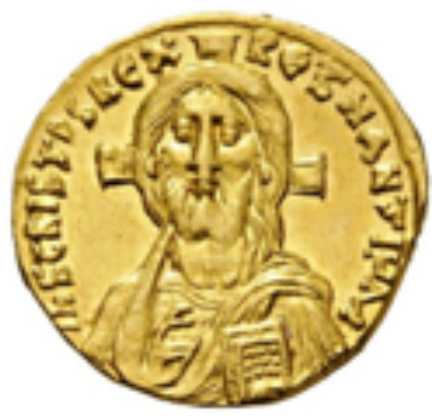

Solidus of Justinian II (685-695)

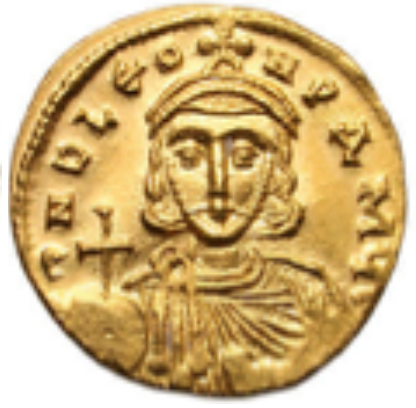

Solidus of Leo III (717-741)

effigies. Thus, not only it is not precise if we say that they were against images but on the contrary, they knew well the power of an image representation.

The last act of this period of anguish is the reign of Michael III, son of the Emperor Theophilos; Michael had to ascend the throne but, being a child and thus not able to govern until his adult age, his mother Theo- 
dora -one of the most intricate personalities of Byzantine history- kept the power and restored definitely the icons. Thus, the annual feast which we speak about here, has been established by her, under her reign, in remembrance of March 11th, $843 \mathrm{AD}$. Formally this day represents the end of this long era of civil clashes, but furthermore it represents also a great development of the self-consciousness of the Byzantine civilization.

\section{The feast as Memory of the Future: the Sunday of Right Thought.}

However, the memory of a past event, of an historical episode, like the one that we have just mentioned, is only a superficial occasion of this feast. The real aim is to represent in front of our eyes our future condition. Icons represent a different kind of physical dimension where the bodies have no shadows because only our world is under the domain of shadow; icons' backgrounds are made of gold because they do not represent a natural landscape where time flows as it normally does; for the same reason, perspective is not used to create an illusion of reality; three-dimensionality is not contemplated by byzantine aesthetics (and therefore neither the practice of sculpture for liturgical purposes), because saints do not live in our earthly condition. The kind of remembrance that icons put in action is not related to the past, but to the future Kingdom; they remind us not only that God became Man, but also that the destiny of sensibility is to be deified. According to John of Damascus «memory is the redemption of sensibility». ${ }^{8}$

Furthermore, let us observe also that icons are just a single element among the entire complex of the orthodox aesthetics of liturgy. Images cannot be celebrated without poetry, incenses, predication, or an appropriate architectural disposition. All the senses should be involved in order to be fully sublated - "sublation» is to be understood in the proper Hegelian sense, because the task here is not to abolish senses, but to raise them up, to drive them beyond themselves. For this reason, the entire liturgy has always been thought in Byzantium as a "synesthetic performance». ${ }^{9}$ The gaze must not be captured by formal beauty and perfection. Mondzain, writes something very similar to this kind of sublation in these terms:

Difficult though this may be to accept, it must be admitted that the icon

[8] John of Damascus, De fide orthodoxa, II §20.

[9] See: M. L. Fobelli, «Santa Sofia. La strategia della luce», in: Procopio di Cesarea, Santa Sofia di Costantinopoli, Jaca Book, Milano 2011, p. 128 
attempts to present the grace of an absence within a system of graphic inscription. Christ is not in the icon; the icon is toward Christ, who never stops withdrawing. And in his withdrawal, he confounds the gaze by making himself both eye and gaze. ${ }^{10}$

This idea of a continuous withdrawal, similar to what I called elsewhere "internal iconoclasm" of the image, has been developed as an answer to artistic, theological and aesthetic problems as well, but only after the historical iconoclasm and in a certain way, thanks to its doctrinal provocation. This is a main reason for which we should insist even today, in our digital era, on its importance.

\section{A Reading of Synodikon.}

Theliturgicaltextpromulgatedattheendoftheiconoclasticwars-butactually compiled during the next four centuries -is called Lvvodıкóv, Synodikon ${ }^{11}$ and contains the decrees of the 7th Ecumenical Council (787). This may help us take a closer look at it, in order to focus better on some issues regarding the specific visual culture advocated in it. Being this text a compilation of several other texts, we should focus only on what concerns particularly the iconoclastic debate and more specifically the thesis to be

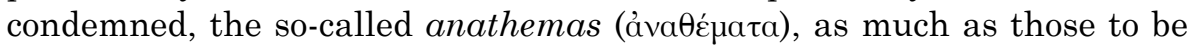
affirmed, the so-called blessings ( $\mu$ акарьбноi) of eternal memory.

\section{a. Anathema to Iconoclasm.}

Every article of Synodikon addressed against heresies is always followed by the word ává $\theta \varepsilon \mu a$. This word presents an interesting ambiguity in its meaning. Anathema could be a curse of eternal damnation, but it

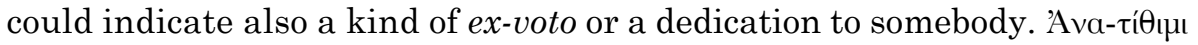
properly means «I entrust myself to someone». The specific use of this term made by the liturgical texts employs both of these meanings in a surprising way, i.e. heretics are to be «entrusted» to God and not simply to the human judgment. ${ }^{12}$ It could sound weird but the anathema is just an offer to God; if we actually conceive it as a damnation it is because of our insuf-

[10] Marie-Jose Mondzain, Image, Icon, Economy, The Byzantine Origins of the Contemporary Imaginary, Stanford University Press, Stanford-California 2005, p. 88.

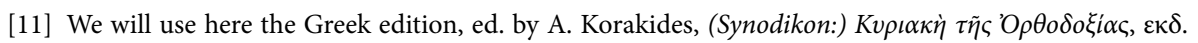

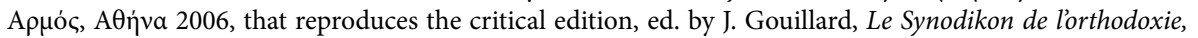
Paris 1967.

[12] Synodikon, p. 13. 
ficiency, our "ontological lack», we may say, in front of God. This thought is rooted and well expressed in the «icon debate».

We may now summarize in five points the arguments against iconoclasts.

1. Our text contains just a mention of a main theological argument, but just in a short paragraph and sounding like this: Iconoclasts accept the «economy of incarnation». ${ }^{13}$ Nonetheless, «incarnation» means that the divine Logos became flesh, as we read in John's Gospel, i.e. He took a human figure and as such acquired visibility: The Infinite became circumscribable or, in reverse, images are really able to re-present God, because God really acquired a sensible presence. Thus, to accept incarnation should mean to accept images. This argument has been sustained and developed by many byzantine authors, from John of Damascus to Nicephorus of Constantinople and beyond. ${ }^{14}$ Our text states well and briefly the entire debate by stating that «they accept the word, but actually they refuse the redemption".

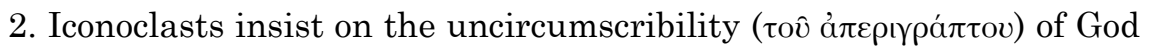
and therefore they deny the possibility of being described in a figure $(\mu \eta$

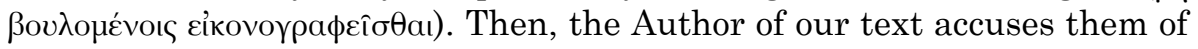

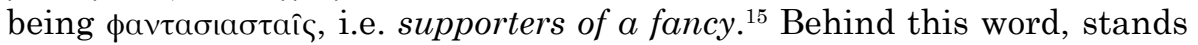

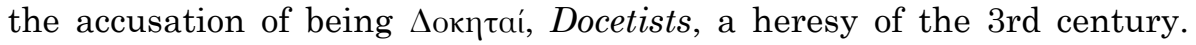
Docetists believed that Jesus was just an appearance of God but not God Himself; according to such a doctrine His human figure was only a fancy, a false body made out of our imagination - that's why they are called «supporters of a fancy». This is another important point from a philosophical point of view. If translated in philosophical terms, the real accusation that stands behind would be that one: iconoclasts do not believe in the truth of phenomena. Notice that even in the Desert Fathers, the appearance is not something false. It could be evil but not false.

3. Iconoclasts generally accept the truth of visions but not of images ${ }^{16}$ to the author of our text it seems a clear contradiction, but if we focus on it, it reveals how Iconoclasts were not naïve at all. The supposed distinction between «legitimacy of vision» and «idolatry of the image» comes up to our days. The film director C. Lanzmann created the unique documentary on the Holocaust without any archive images that would pretend to testify

[13] Ibid., p. 36.

[14] John of Damascus, On the divine images: the apologies against those who attack the divine images, trans. by D. Anderson, New York: St. Vladimir's Seminary Press, 1980.

[15] Synodikon, p.38.

[16] Ibid.p. 40. 
the truth of the past. ${ }^{17}$ However, he creates in fact a visual product. As a modern iconoclast, he knows well the power of images.

4. If iconoclasts deny the image-representation of all the acts and deeds of Jesus, they should even deny his passion that happened in history, and thus, his historical existence and the possibility of transmission and imitation of his acts. ${ }^{18}$ Images are the most valuable means of remembrance and transmission of a doctrine. This point was especially promoted by the Latin Church and could be summarized in the notion of memoria rerum gestarum. ${ }^{19}$

5. Iconoclasts should be considered alike the Jews and Greeks and even worst. According to the author of our text, Greek Pagans, even if they did not insult the images, they do insult their Prototypon, the Unique God. Jews, on the contrary, even if they respect the same God, by insulting the images they end up insulting the one who is there depicted..$^{20}$ Therefore, the

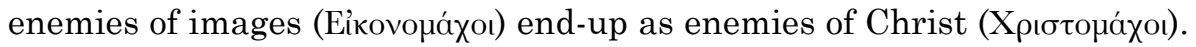
This is a negative formulation of another iconophilic argument that we could call the transitive property of the image. We will return back to this in a while, speaking about the thesis of Basil the Great.

\section{b. Eternal Memory of the true faith.}

Setting to aside the anathemas, if we look to the blessings, we could observe a strange opening: the author speaks about the sense of the word «ecclesia». He explains that it is "not simply the buildings and the embellishments of the temples, but rather the congregation". For what reason does he make this statement, without apparent direct relationship to the rest? Perhaps, he wanted to answer to the accusation that iconophiles worship material things. To adore God in Spirit and not in colors and forms, as iconophiles wanted, was a constant claim of the iconoclasts. ${ }^{21}$

Thus, the author assures us clearly that spiritual worship is the main point for iconophiles too; but immediately after, he attempts to embrace all

[17] See his documentary Shoah (France, 1985).

[18] Synodikon, p. 40

[19] Libri Carolini I, 10; see: M. Bettetini, «Carlo Magno e Gioacchino da Fiore prima di Trento e Hollywood», in: Ontologia dell'immagine, ed. by G. Cantillo et al., Aracne, Roma 2012, pp. 45-74, p. 64 f.

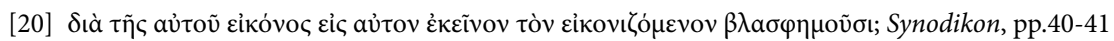

[21] Textus byzantinos ad iconomachiam pertinentes, ed. by H. Hennephof, Brill, Leiden 1969, frag. 280; One of the few iconoclastic monuments that survived, the church of Hagia Eirene in Constantinople, is a clear proof of what iconoclasts were thinking about embellishments. 
the arts. The first reference is to hymns and poetry; ${ }^{22}$ right after he affirms the importance of a full aesthetic experience. In fact, the right thought, the right faith is proper to those who "confess with word, mouth, heart, and mind, and with both writing and icons the incarnate advent of God-Logos». «Both writing and icons» expresses the real purpose of this feast, i.e. the equivalence of word and image and not just the supremacy of the image as many people still believe. On another point, it is said:

To them who (...) proclaim the doctrines by means of writings and the deeds by means of forms, and link them together because the benefit is common, whereby the truth is affirmed in word and confirmed in the icon, Eternal Memory. ${ }^{23}$

The word affirms and the icon confirms. A philosophical understanding of this statement could be that the concept of God, at first, is grasped abstractly, in its universality; that means that it is just affirmed positively. Secondly it should be transferred and concretized in the sensuous perception. In terms of philosophy of religion, there is a good explanation for this procedure, given by Hegel in his Lectures on this argument:

the consciousness of the absolute idea that we have in philosophy in the form of thinking is to be brought forth not for the standpoint of philosophical speculation (...) but in the form of certainty. (...). In other words, this content - the unity of divine and human nature - achieves certainty, obtaining the form of immediate sensible intuition and external existence for humankind, so that it appears as something that has been seen in the world, something that has been experienced. It is essential to this form of non-speculative consciousness that it must be before us; it must essentially be before me - it must become a certainty for humanity. ${ }^{24}$

This «being in front of» (vor sich haben, vor mir sein), is nothing but the human ability for representation, (vor-stellung). To re-present is to put in front of us a new dimension of what was once simply present. In this sense, this feast could be also understood as a celebration of the necessity of representation. The word affirms, but the image confirms, because it gives certainty to the intuition, or in orthodox terms, it attributes "to the one Hypostasis both the created and uncreated, the visible and invisible, the passible and impassible, the circumscribable and uncircumscribable». Those who do really recognize this image-mechanism are called by our

[22] «those who there (in the Ecclesia) serve the Divinity with hymns and doxologies».

[23] Synodikon, p. 28.

[24] See: G.W.F. Hegel, Vorlesungen über die Philosophie der Religion, t.3 (1827), pp. 237 ff.; Lectures on Philosophy of Religion, vol.III, University of California Press, Berkeley 1985, pp. 312 f. 


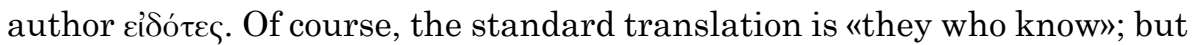
notice that in Greek it literally means «they who see». The act of knowing is always related with the act of seeing.

There is another important verse that I would like to connect to this one. At the beginning of our text, the author thanks God for providing people with such a holy feast and for having «restored», «repaired» or «com-

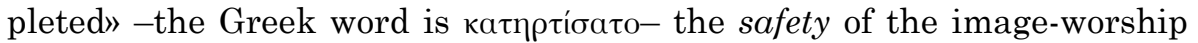

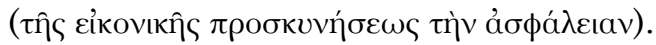

However, what does the word safety really mean here? An obvious answer would be that it refers to the historical moment of civil wars, namely to the "security" gained by iconophiles after the iconoclastic persecutions; however, from another point of view, "safety" would be the "safest way to honor the images». The first option seems obviously closer to the historical context. Moreover, if we think that scholars such as Leslie Brubaker raised serious doubts about the effectiveness of the persecutions and about the reliability of the iconophile historical sources, then we could also think that our Author does not refer to the security in the sense of social order, but to the safest way to honor images, established by the Seventh Ecumenical Synod, as the very beginning for a systematic theology of icons.

In any case, the relationship between the act of seeing and the act of understanding, not only attributes to the gaze of an indeterminate overestimation, but implies also a duty of systematization, as if it was about the organization of a real system of knowledge. Here it comes forth, the consciousness of the necessity to regulate the gaze in order to be able to understand better and this is another important point about this feast. In another significant verse of the text it is said:

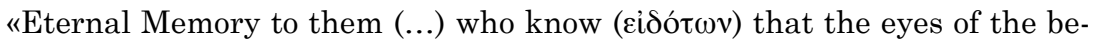
holders are (...) sanctified through the venerable icons, and through them the mind is lifted to God-knowledge, as well as by the divine temples also, the sacred vessels, and the other precious ornaments».

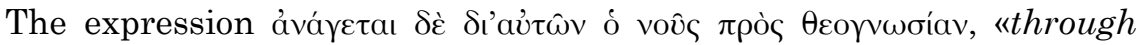
them, the mind is lifted to God-knowledge», is crucial to comprehend the doctrine of icons. The small preposition $\delta i$, "through", which is not even a concept, means actually to move through the image and leave it behind. ${ }^{25}$ It is found in one of the most famous passages of the patristic literature, the writing of Basil the Great On the Holy Spirit, where this proposition is elevated to the concept; there he speaks about the meaning and the defer-

[25] We saw before the same function of dia in its negative expression, in the fifth point against iconoclast, where the blasphemy was passing through icon to God. 
ence between 'honoring' and 'worshiping': when we look at the image of a King we do not say that there are two kings; thus we do not pay honor to

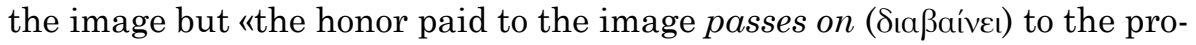
totype». ${ }^{26}$ This is what we may call the transitive quality of images. Many centuries later, the Russian philosopher Pavel Florenskij said that icons are like windows. A window is really what it is only when it lets sunlight pass through. If not, it is more alike to a wall; thus, in itself, image is just this letting-pass through. ${ }^{27}$ Therefore, if the Icon does not leave our gaze to transit to the other side, it is not an icon but a piece of wood. That's why it seems to me that the image has an ontological consistency only when it falls away. According to my approach, what this feast celebrates is the ultimate sublation of the image itself. The more the image fulfills its own essence, the more it should disappear.

\section{Some considerations on Byzantine legacy.}

Now we could go back to what Debray called the threefold source of our contemporary visual culture and try to watch them according to our small preposition that demands a sublation. The question now sounds like this: if transitive property is inherent to every image, thus where does each one of these images really lead us? The first one, the byzantine icon, is a strictly regulated image by the canons of tradition; it leads us to somebody who is clearly not a living person: her hands, her face, her light, are similar to ours, but they are not ours. She is not just imaginary; it supposed that she had a historical existence, but she does not belong to history.

The second one, the baroque image, a painting regulated by the genius of the painter, shows us a beautiful woman modeled on the perfection of geometrical and mathematical patterns. She is ideal and she transcends our decay. Our gaze does not go into the darkness of inexpressible mysteries but to the perfection of forms that surround our world in its entire splendor.

Then comes the third one, the star of Hollywood, captured in a moment by photography. We used to call it a portrait, but actually it is a still-life. She does not drive us elsewhere, not in mysteries, nor in ideas. There is not a hidden doctrine but the surface is the doctrine. Her beauty does not make us desire another world but this world. Notice that behind each one of these three pictures, we find three different ways of image-production:

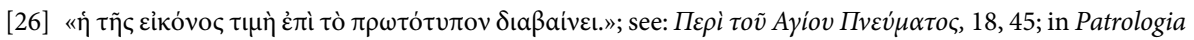
Graeca, ed. by Migne, vol. 32, p.149.

[27] See: P. Florenskij, Iconostasis, Oakwood Publications, Torrance-California 1996, p. 65. 
the first image is made of pigments on wood; the second is made of oil painting on canvas; the third is an analog photography: different technics, for different purposes.

It should be evident that the threefold sequence describes an always-greater effort to grasp «better» the Real. They could be seen as landmarks in the history of our attempt to reproduce a $h i$ - $f$ image. Our supposed High-fidelity to the Real, is inversely proportional to our Low-faith. Each one of these images are a product of specific forces, of different (political and technological) apparatus. Hence, in photography the illusion of immediacy is stronger, or it would be better to say, the illusion is stronger because of the immediacy. The path of progress led us suddenly to ground zero. The most concrete results, in reality, as the most abstract. The transitional property of the image, therefore, is interrupted.

Icon represents a model that is eternally withdrawal; baroque painting re-presents a model that is eternally present; and the technological image presents nothing but the present, in an eternal repetition. Let us notice something more: the first two images are the cultural product of two different moments of victory over iconoclasm (the byzantine one and the protestant one). The third image is the only one that does not have any cultural critique, or any doctrinal debate: coup d'etat of the image. A byzantine hagiographer or a sixteenth century painter, had to reflect on how should he create an image in order to lift the mind to God-knowledge. The photographer, instead, reflects on how should he create an image in order to capture the mind in it.

Images are not political, nor totalitarian, not mythical nor mystical. They create an illusionary history, positively or negatively, through concrete acts of iconoclasm, as for instance the obliteration; they just offer us, the metaphysically analphabets, a new Biblia pauperum according to the image-politics promoted, not by the Pope of Rome or by Charles the Great, but by the Market. Images are not evil creations; they

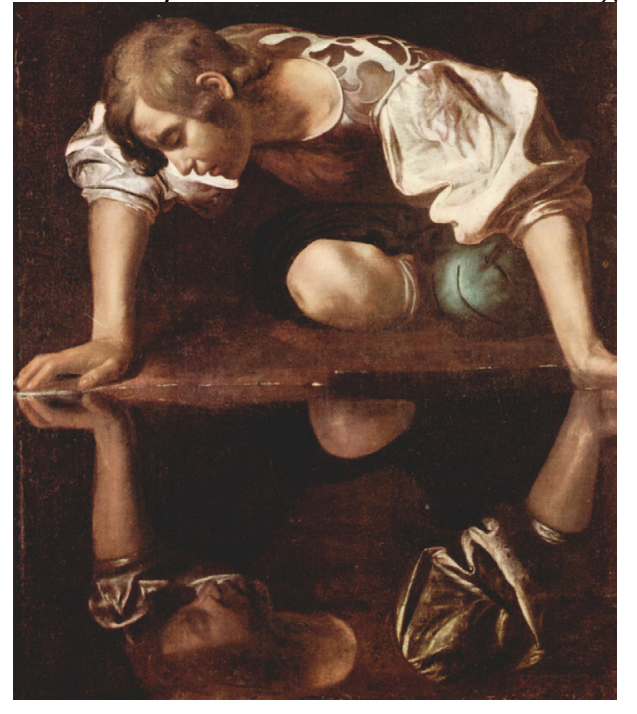

Caravaggio, Narciso, 1597-1599, oil on canvas, $112 \times 92 \mathrm{~cm}$, Galleria Nazionale d'Arte Antica-Palazzo Barberini, Roma 
just became reflecting walls of our emptiness and it is this reflecting power that scares really.

The myth of Narcissus today is more than ever up to date. It is interesting to notice that the point of the story was not that Narcissus fell in love of his double (with all its psychoanalytic consequences) nor that he drowned into the waters pursuing his eidolon (with all its philosophical

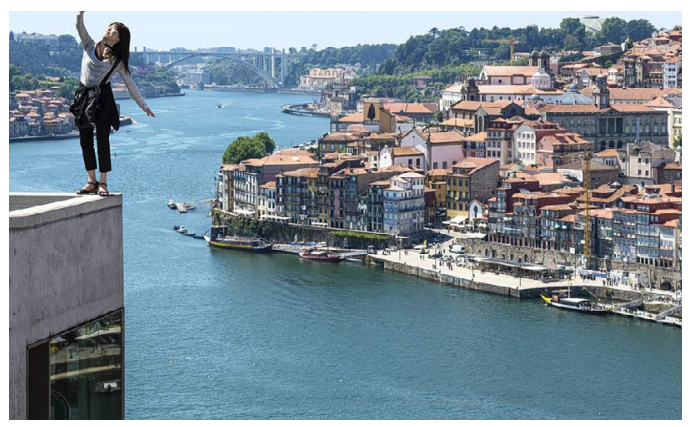
consequences, highlighted by Plotinus $\operatorname{too}^{28}$ ); but the point was the fact that right after his death -as Ovid tells us clearly but nobody mentions today- he continued being mirrored in the waters of the river of the Underworld for eternity ${ }^{29}$.

His punishment was not to die because of the vision; but to keep being mirrored and prisoner of his own gaze for the rest of eternity. Who knows if people dying today trying to take a selfie, will really keep taking selfies in the afterlife too? The Desert Fathers that we quoted at the beginning, was speaking literally about selfies, by saying that the first cause of illusion is the "intellectual self-esteem».

The feast of icons does not advocate the love of images (as modern iconodules do) but the love through images of a living relationship; on the other hand, it does not condemn images (as iconophobic moralists do), but assumes their necessity in our spiritual life. It is an important chapter of our visual culture, not because it generated Hollywood, but because it reminds us that we have to celebrate not the visible, but through the visible the invisible, offering in that way a transitional model to our thought which develops the dialectics between memory and imagination, giving an image to what is not present anymore and to what is still to come. To educate our eyes to look through the image and not just the image itself, it is the very act of what we could call an «iconoclastic love for images». Perhaps, after all, the wolf may be just an invention of the shepherd himself.

[28] See: Plotinus, Enneads I, 6, 8.

[29] See: Ovid, Metamorphoses, III, vv. 402-510, particularly: vv.504 s. 